University of Nebraska - Lincoln

DigitalCommons@University of Nebraska - Lincoln

2008

\title{
Moderate zinc restriction affects intestinal health and immune function in lipopolysaccharide-challenged mice
}

Daniel G. Peterson

California Polytechnic State University - San Luis Obispo, dpeterso@calpoly.edu

Angus G. Scrimgeour

U.S. Army Research Institute of Environmental Medicine

James P. McClung

U.S. Army Research Institute of Environmental Medicine

Elizabeth A. Koutsos

California Polytechnic State University - San Luis Obispo

Follow this and additional works at: https://digitalcommons.unl.edu/usarmyresearch

Part of the Operations Research, Systems Engineering and Industrial Engineering Commons

Peterson, Daniel G.; Scrimgeour, Angus G.; McClung, James P.; and Koutsos, Elizabeth A., "Moderate zinc restriction affects intestinal health and immune function in lipopolysaccharide-challenged mice" (2008). US Army Research. 145.

https://digitalcommons.unl.edu/usarmyresearch/145

This Article is brought to you for free and open access by the U.S. Department of Defense at DigitalCommons@University of Nebraska - Lincoln. It has been accepted for inclusion in US Army Research by an authorized administrator of DigitalCommons@University of Nebraska - Lincoln. 


\title{
Moderate zinc restriction affects intestinal health and immune function in lipopolysaccharide-challenged mice $\mathrm{s}^{\text {t3 }}$
}

\author{
Daniel G. Peterson $^{\mathrm{a}, *}$, Angus G. Scrimgeour ${ }^{\mathrm{b}}$, James P. McClung ${ }^{\mathrm{b}}$, Elizabeth A. Koutsos ${ }^{\mathrm{a}}$ \\ a Animal Science Department, California Polytechnic State University, San Luis Obispo, CA 93407, USA \\ ${ }^{\mathrm{b}}$ Military Nutrition Division, U.S. Army Research Institute of Environmental Medicine, Natick, MA 01760, USA \\ Received 10 October 2006; received in revised form 1 February 2007; accepted 14 February 2007
}

\begin{abstract}
Zinc $(\mathrm{Zn})$ is an essential nutrient that affects immune function, especially within the digestive system, although the underlying mechanisms are not well understood. This study examined the effects of short-term moderate $\mathrm{Zn}$ restriction on intestinal health and immune function in lipopolysaccharide (LPS)-challenged mice through plasma cytokine profiling and histological evaluation of intestinal tissue sections. Adult male mice were fed with a Zn-adequate $(40 \mathrm{ppm})$ or a $\mathrm{Zn}$-marginal $(4 \mathrm{ppm})$ diet for 4 weeks, and then a bacterial challenge was simulated by intraperitoneal injection of LPS (10 $\mu \mathrm{g} / \mathrm{g}$ body weight [BW]) or saline (control). BW was recorded weekly, and feed intake was recorded daily over the last week. Voluntary locomotor activity was assessed 6 and $24 \mathrm{~h}$ after the challenge. Plasma and tissues were collected 0,6 or $24 \mathrm{~h}$ after the challenge for analysis. Histological analysis of intestinal samples included evaluation of villi length and width, lamina propria (LP) width, crypt depth and intraepithelial as well as LP leukocyte numbers. Plasma was analyzed for IL-1 $\beta$, IL-4, IL-6, IL10, IL-12p40, IL-12p70, interferon gamma and tumor necrosis factor $\alpha$. Diet did not affect BW and feed intake. The LPS challenge led to decreased voluntary locomotor activity $(P<.05)$. Moderate $\mathrm{Zn}$ restriction led to greater leukocyte infiltration in the LP after the LPS challenge $(P<.05)$ and higher plasma IL-6 and IL-10 levels $24 \mathrm{~h}$ after the LPS challenge $(P<.01)$. Results indicate that $\mathrm{Zn}$ status impacts intestinal responses to LPS through modulation of the cytokine response and leukocyte recruitment, and this impact is evident even with short-term (4 weeks) moderate $\mathrm{Zn}$ restriction.

(C) 2008 Elsevier Inc. All rights reserved.
\end{abstract}

Keywords: Mice; Zinc; Immune response; Cytokines; Intestine

\section{Introduction}

Zinc $(\mathrm{Zn})$ is a nutritionally essential trace element that functions in numerous metabolic pathways. It plays a critical role in immune function (reviewed in Reference [1]) as moderate $\mathrm{Zn}$ deficiency and severe Zn deficiency are known to affect immunity in human and nonhuman models $[2,3]$. Zn status affects numerous lymphocyte functions including

\footnotetext{
it The opinions or assertions contained in this article are the private views of the authors and are not to be construed as official or as reflecting the views of the Army or the Department of Defense. Any citation of commercial organizations and trade names in this report does not constitute an official Department of the Army endorsement of approval of the products or services of these organizations.

* Corresponding author. Tel.: +1 805756 7633; fax: +1 8057565069 .

E-mail address: dpeterso@calpoly.edu (D.G. Peterson).
}

mitogenesis, antibody synthesis and other facets of cellmediated immunity, which are negatively impacted by $\mathrm{Zn}$ deficiency (reviewed in Reference [4]). Humoral immunity is also affected by Zn deficiency, which induces B-lymphocyte apoptosis and reduces antibody responses (reviewed in Reference [5]), although Zn deficiency does not affect the production of IL-4, IL-6 and IL-10 [6] cytokine expression in either nonchallenged or immune-challenged cells and animals $[7,8]$. Zn deficiency decreases IL-2 $[6,9,10]$ and interferon gamma (IFN $\gamma ;[6,7,10])$ production by peripheral blood mononuclear cells (PBMCs) but increases tumor necrosis factor $\alpha(\mathrm{TNF} \alpha)$ production by endothelial cells [11] and innate immune cells $[8,10]$. Similarly, moderate $\mathrm{Zn}$ restriction increases IL-1 $\beta$ production by PBMCs $[6,8,10]$ and IL-8 messenger RNA expression [10].

$\mathrm{Zn}$ is also implicated in diarrhea due to its effects on intestinal mucosal permeability [12] and the ability of dietary 
$\mathrm{Zn}$ to prevent or alleviate intestinal diseases [13]. At pharmacological levels, this effect may be due to the antimicrobial properties of $\mathrm{Zn}$ (e.g., [14]) and disruption of bacterial-enterocyte binding as well as subsequent bacterial translocation [15]. However, at physiological levels, it is more likely that Zn affects intestinal physiology and immune function through its effects on cytokine production, as mentioned above.

The level of dietary $\mathrm{Zn}$ examined is a critical component of any investigation of the effect of $\mathrm{Zn}$ status on intestinal immune function and systemic immune function. Immune modulation by $\mathrm{Zn}$ has typically been studied in the context of frank $\mathrm{Zn}$ deficiency, although moderate $\mathrm{Zn}$ deficiency is of interest because this nutritional condition is difficult to diagnose - yet classical studies have demonstrated increased growth of $\mathrm{Zn}$-supplemented children even from middle to upper socioeconomic classes in the United States and Canada $[16,17]$. This trial compared $\mathrm{Zn}$ adequacy with moderate $\mathrm{Zn}$ restriction in adult animals in order to assess the primary effects of $\mathrm{Zn}$ restriction in the absence of secondary effects such as impaired growth and decreased intake.

Intestinal immune function is often studied in the context of oral administration of a pathogen or an immunogenic compound. However, the use of live pathogens is of concern due to limitations on quantification of the exact number of organisms and their proliferative capacity after the challenge. Therefore, this trial examined a non-oral challenge that elicited intestinal and systemic immune responses.

The objectives of the present study were to determine the ability of an intraperitoneal challenge to elicit intestinal and systemic immune responses and to examine the effects of moderate $\mathrm{Zn}$ restriction on these intestinal responses as well as on systemic cytokine concentrations in adult male mice.

\section{Materials and methods}

\subsection{Animals and treatments}

All procedures were approved by the California Polytechnic State University Institutional Animal Care and Use Committee. Male BALB/c mice ( $n=96,6$ weeks old, mean body weight $(\mathrm{BW})=20.05 \mathrm{~g}$; Harlan, Indianapolis, IN, USA) were housed in eight cages $(n=12 /$ cage), and each cage was supplied with either a Zn-adequate $(40.1 \pm 4.2 \mathrm{ppm})$ or a $\mathrm{Zn}$ marginal $(3.9 \pm 1.8 \mathrm{ppm})$ diet (Research Diets, New Brunswick, NJ, USA) for 4 weeks. Zn content of feed was assessed using flame atomic absorption spectroscopy (Perkin Elmer 2380, Perkin Elmer, Norwalk, CT, USA). Feed ( $\sim 1.0 \mathrm{~g}$ of each diet) samples were diluted eightfold with 5\% nitric acid (trace metal grade, Fisher Scientific, Pittsburgh, PA, USA). $\mathrm{Zn}$ standards, prepared from a reference solution (Fisher Scientific) in 5\% nitric acid, were used as internal control. All analyses were conducted in acid-washed glassware. Recovery tests were performed to confirm the accuracy of the abovementioned method, and the recovery of $\mathrm{Zn}$ was $108 \pm 1.1 \%$ ( $n=5, \mathrm{CV}=2.3 \%)$. In order to avoid environmental exposure to $\mathrm{Zn}$, animals were allowed free access to deionized water at all times and were housed in plastic cages. BW was recorded weekly throughout the study, and feed intake was recorded daily for the last week of the study.

After 4 weeks of the dietary treatments, half of the animals in each cage $(n=6)$ were exposed to intraperitoneal injection of saline $(0.2 \mathrm{ml}$, control) and the other half $(n=6)$ were injected with lipopolysaccharide (LPS; $10 \mu \mathrm{g} / \mathrm{g} \mathrm{BW}$ in $0.2 \mathrm{ml}$ ) to simulate a bacterial challenge. LPS (intraperitoneal route) has previously been shown to induce monocyte adhesion and infiltration into intestinal tissues of mice [18]; thus, it was predicted that LPS would induce intestinal distress, similar to other diarrhea models. Four animals from each cage (two control and two LPS) were euthanized by $\mathrm{CO}_{2}$ asphyxiation for sample collection 0,6 and $24 \mathrm{~h}$ after the intraperitoneal challenge.

\subsection{Behavioral analysis}

Prior to sample collection, animals were assessed for voluntary locomotor activity by a method adapted from the work of Cravatt et al. [19]. Briefly, each mouse was placed in the center of a $78 \times 56-\mathrm{cm}$ cage marked with $7-\mathrm{cm}^{2}$ grid lines on the bottom, and the number of squares traversed in $1 \mathrm{~min}$ was recorded.

\subsection{Tissue sample collection}

Immediately after euthanasia, blood was collected into heparinized tubes and plasma was isolated and frozen at $-20^{\circ} \mathrm{C}$ for cytokine analysis. Subsequently, intestinal samples were isolated from animals $24 \mathrm{~h}$ after the challenge. Jejunum samples were isolated from the intestine immediately distal to the pancreatic loop. Ileum samples were isolated from the midpoint between the jejunum and the ileocecal junction. Each intestinal sample was immediately washed with cold saline and then rinsed with $10 \%$ formalin, recut to $\sim 2-\mathrm{cm}$ sections and placed in $10 \%$ formalin jars for embedding and hematoxylin-eosin staining by a commercial laboratory (IDEXX, West Sacramento, CA, USA).

\subsection{Plasma cytokine analysis}

Plasma cytokine analysis was performed using Bio-Plex mouse cytokine assay panels (Bio-Rad Laboratories, Hercules, CA, USA) analyzed using a Luminex 100 analyzer (Luminex, Austin, TX, USA). Cytokines analyzed were IFN $\gamma$, IL-1 $\beta$ IL-4, IL-5, IL-6, IL-10, IL-12p40, IL-12p70 and TNF $\alpha$.

\subsection{Histological analysis of intestinal sections}

For each intestinal section (per animal), three villi were randomly selected to measure villus length, villus width, lamina propria (LP) width and crypt depth as well as to count leukocytes in the LP and intraepithelial regions. Using a $5 \times$ field, villus length was evaluated as the distance from the apical region to the base of the villus and villus width was evaluated as the distance from one side of the brush border 
Table 1

Feed intake and BW of animals fed with a $\mathrm{Zn}$-adequate (Ad-Zn) diet and those fed with a $\mathrm{Zn}$-marginal (Lo-Zn) diet

\begin{tabular}{lrrr}
\hline & Lo-Zn diet & Ad-Zn diet & $P$ \\
\hline Intake (g/day) & $2.59 \pm 0.06$ & $2.56 \pm 0.05$ & .52 \\
Initial BW (g) & $20.34 \pm 0.33$ & $19.76 \pm 0.12$ & .12 \\
Final BW (g) & $24.32 \pm 0.26$ & $23.65 \pm 0.23$ & .07 \\
\hline
\end{tabular}

Intake was measured daily during Week 4 , and BW was measured weekly across the 4 -week experiment ( $n=4$ cages/diet, 12 animals/cage). Values are expressed as mean \pm S.E.M.

membrane to the other side of the brush border membrane [20]. Using a $10 \times$ field, LP width was determined by measuring the width of the vascular region in the center of the villus $[21,22]$ and crypt depth was measured as the depth of the invaginations located at the base of each villus. Leukocytes were identified and counted as described by Bjerregaard [23].

\subsection{Statistical analysis}

All dependent variables were analyzed using a general linear model (JMP, SAS, Cary, NC, USA) with analysis of variance to determine the main effects of diet, challenge, time after the challenge (not included for intestinal histology) and their interactions. When interactions were not significant $(P>.20)$, they were removed from the model. Tukey's HSD (honestly significant difference) was used to assess differences among all pairwise comparisons. Cage was initially included in the statistical analysis, but it was found to be nonsignificant in all cases and subsequently dropped from the model. Differences were considered significant at $P<.05$.

\section{Results}

Consumption of the $\mathrm{Zn}$-marginal diet for 4 weeks did not affect feed intake over the last week of the study, BW change over the course of the study, and initial or final BW (Table 1).

Visual observation revealed that challenge with LPS resulted in severe diarrhea 6 and $24 \mathrm{~h}$ after the challenge. Voluntary locomotor activity was significantly affected by the LPS challenge; saline-challenged mice had greater

Table 2

Voluntary locomotor activity of mice 6 or $24 \mathrm{~h}$ after challenge by intraperitoneal injection of LPS or saline after 4-week treatment with either an Ad-Zn or an Lo-Zn diet ( $n=4$ cages/diet, 6 animals/cage for each challenge, 12 animals/cage in total)

\begin{tabular}{llllll}
\hline $\begin{array}{l}\text { Time after } \\
\text { challenge }(\mathrm{h})\end{array}$ & Saline & & \multicolumn{2}{l}{ LPS } \\
\cline { 2 - 3 } \cline { 6 - 7 } & Lo-Zn & Ad-Zn & & Lo-Zn & Ad-Zn \\
\hline 6 & $28.3 \pm 4.9^{\mathrm{a}}$ & $21.0 \pm 4.5^{\mathrm{a}}$ & & $6.5 \pm 2.3^{\mathrm{b}}$ & $3.5 \pm 0.9^{\mathrm{b}}$ \\
24 & $26.0 \pm 6.7^{\mathrm{a}}$ & $30.5 \pm 9.7^{\mathrm{a}}$ & & $3.6 \pm 1.3^{\mathrm{b}}$ & $4.6 \pm 2.6^{\mathrm{b}}$ \\
\hline
\end{tabular}

Activity was assessed by placing animals in a $78 \times 56$-cm cage marked with $7-\mathrm{cm}^{2}$ grid lines and by counting the number of squares traversed in $1 \mathrm{~min}$. Values are expressed as mean \pm S.E.M. Differing superscripts within a row indicate significant differences $(P<.05)$. activity than did LPS-challenged animals (26.4 traversed squares vs. 4.5 traversed squares, as pooled means for both time points and both diet groups, $P<.05$; Table 2).

The immune challenge also affected plasma cytokine concentrations (Table 3). Specifically, LPS increased plasma IL-6, IL-10, IL-12p40, IFN $\gamma$ and TNF $\alpha(P<.05$ for each) but decreased plasma IL-4 and IL-12p70 ( $P<.05$ for each). The $\mathrm{Zn}$-marginal diet led to an overall increase (across all time points and for LPS and saline groups combined) in IL-6 $(P<.05)$, with a similar trend for IL-10 $(P=.07)$. Of greatest interest is the interaction of diet and LPS challenge on plasma IL-6 and IL-10 ( $P<.05$ for each), for which concentrations of each cytokine were elevated $6 \mathrm{~h}$ after the LPS challenge for mice fed with either diet but remained elevated $24 \mathrm{~h}$ after the injection only for mice fed with the Zn-marginal diet (Fig. 1).

Intestinal histology was affected by diet and the LPS challenge. In the jejunum $24 \mathrm{~h}$ after the challenge, LPS resulted in decreased villus length and increased crypt depth $(P<.05$ for each; Fig. 2A) as well as increased numbers of leukocytes in the intraepithelial and LP regions $(P<.05$;

Table 3

Mean plasma cytokine concentrations (pg/ml) of mice 0,6 or $24 \mathrm{~h}$ after challenge by intraperitoneal injection of LPS or saline after 4-week treatment with either an Ad-Zn or an Lo-Zn diet ${ }^{\mathrm{a}}$

\begin{tabular}{|c|c|c|c|c|c|c|c|c|}
\hline & \multicolumn{3}{|l|}{ LPS } & \multicolumn{3}{|l|}{$\underline{\text { Saline }}$} & \multirow[t]{2}{*}{ S.E.M. } & \multirow[t]{2}{*}{ Effect } \\
\hline & $0 \mathrm{~h}$ & $6 \mathrm{~h}$ & $24 \mathrm{~h}$ & $0 \mathrm{~h}$ & $6 \mathrm{~h}$ & $24 \mathrm{~h}$ & & \\
\hline \multicolumn{9}{|l|}{ IL-1 $\beta$} \\
\hline $\mathrm{Ad}-\mathrm{Zn}$ & 18.1 & 87.4 & 13.9 & 20.5 & 10.7 & 21.6 & \multirow[t]{2}{*}{15.2} & \multirow[t]{2}{*}{ NS } \\
\hline Lo-Zn & 31.2 & 194.7 & 42.4 & 35.6 & 9.7 & ND & & \\
\hline \multicolumn{9}{|c|}{ IL-4 } \\
\hline Ad-Zn & 22.0 & 6.9 & 6.1 & 34.9 & 15.8 & 34.7 & \multirow[t]{2}{*}{2.0} & \multirow[t]{2}{*}{$\mathrm{C}, \mathrm{T}$} \\
\hline Lo-Zn & 28.2 & 8.0 & 2.9 & 25.5 & 8.1 & ND & & \\
\hline \multicolumn{9}{|c|}{ IL-5 } \\
\hline Ad-Zn & 0 & 18.3 & 7.5 & 5.9 & 13.5 & 0 & \multirow[t]{2}{*}{1.6} & \multirow[t]{2}{*}{$\mathrm{T}$} \\
\hline Lo-Zn & 0 & 27.2 & 12.6 & 1.2 & 16.1 & ND & & \\
\hline \multicolumn{9}{|l|}{ IL-6 } \\
\hline Ad-Zn & 1.5 & 4865.6 & 1009.5 & 2.2 & 38.7 & 2.2 & \multirow[t]{2}{*}{320.0} & \multirow{2}{*}{$\begin{array}{l}\mathrm{D}, \mathrm{C}, \mathrm{T} \\
\mathrm{C} \times \mathrm{T}, \mathrm{D} \times \mathrm{T}\end{array}$} \\
\hline Lo-Zn & 2.3 & 4540.6 & 5066.2 & 2.1 & 1.6 & ND & & \\
\hline \multicolumn{9}{|l|}{ IL-10 } \\
\hline Ad-Zn & 0 & 108.8 & 68.9 & 0 & 2.0 & 9.1 & \multirow[t]{2}{*}{13.6} & $\mathrm{D}, \mathrm{C}, \mathrm{T}$ \\
\hline Lo-Zn & 0 & 152.4 & 221.8 & 0 & 0 & ND & & $\mathrm{C} \times \mathrm{T}, \mathrm{D} \times \mathrm{T}$ \\
\hline \multicolumn{9}{|l|}{ IL-12p40 } \\
\hline Ad-Zn & 187.5 & 481.1 & 143.7 & 219.7 & 250.6 & 284.5 & \multirow[t]{2}{*}{24.6} & \multirow[t]{2}{*}{$\mathrm{T}, \mathrm{C} \times \mathrm{T}$} \\
\hline Lo-Zn & 271.9 & 508.5 & 108.9 & 227.5 & 170.6 & ND & & \\
\hline \multicolumn{9}{|l|}{ IL-12p70 } \\
\hline Ad-Zn & 158.4 & 29.9 & 12.1 & 179.0 & 96.4 & 228.7 & \multirow[t]{2}{*}{15.4} & \multirow[t]{2}{*}{$\mathrm{C} \times \mathrm{T}$} \\
\hline Lo-Zn & 234.5 & 35.3 & 16.1 & 193.5 & 22.3 & ND & & \\
\hline \multicolumn{9}{|c|}{ IFN $\gamma$} \\
\hline Ad-Zn & 458.0 & 892.1 & 252.0 & 577.6 & 438.7 & 750.7 & \multirow[t]{2}{*}{73.9} & \multirow[t]{2}{*}{$\mathrm{C} \times \mathrm{T}$} \\
\hline Lo-Zn & 643.2 & 1297.9 & 297.7 & 530.5 & 267.2 & ND & & \\
\hline \multicolumn{9}{|c|}{$\mathrm{TNF} \alpha$} \\
\hline Ad-Zn & 0 & 175.3 & 25.5 & 0.8 & 0.2 & 0 & \multirow[t]{2}{*}{14.7} & \multirow[t]{2}{*}{$\mathrm{D}, \mathrm{C}, \mathrm{T}$} \\
\hline Lo-Zn & 0.4 & 215.1 & 127.7 & 0 & 0.3 & ND & & \\
\hline
\end{tabular}

${ }^{\text {a }}$ Standard error represents the pooled S.E.M. for each cytokine. The effect of diet (D), challenge (C), time (T) or interactions was considered significant at $P<.05$ and is listed in the last column. ND indicates not determined; NS, not significant. 
Fig. 2B). Zn status did not significantly affect surface area measurements in the jejunum $(P>.1$ for all; Fig. $3 \mathrm{~A})$, but mice fed with the Zn-marginal diet had significantly greater leukocyte numbers in the intraepithelial region $(P<.05$; Fig. 3B). Additionally, an interaction between diet and challenge demonstrated that mice fed with a Zn-marginal diet and challenged with LPS had greater numbers of intraepithelial leukocytes in the jejunum as compared with $\mathrm{Zn}$-adequate animals (Diet $\times$ Challenge interaction, $P<.05$; Fig. 4).

In the ileum $24 \mathrm{~h}$ after the challenge, LPS increased crypt depth $(P<.05$; Fig. 5A) and led to greater numbers of
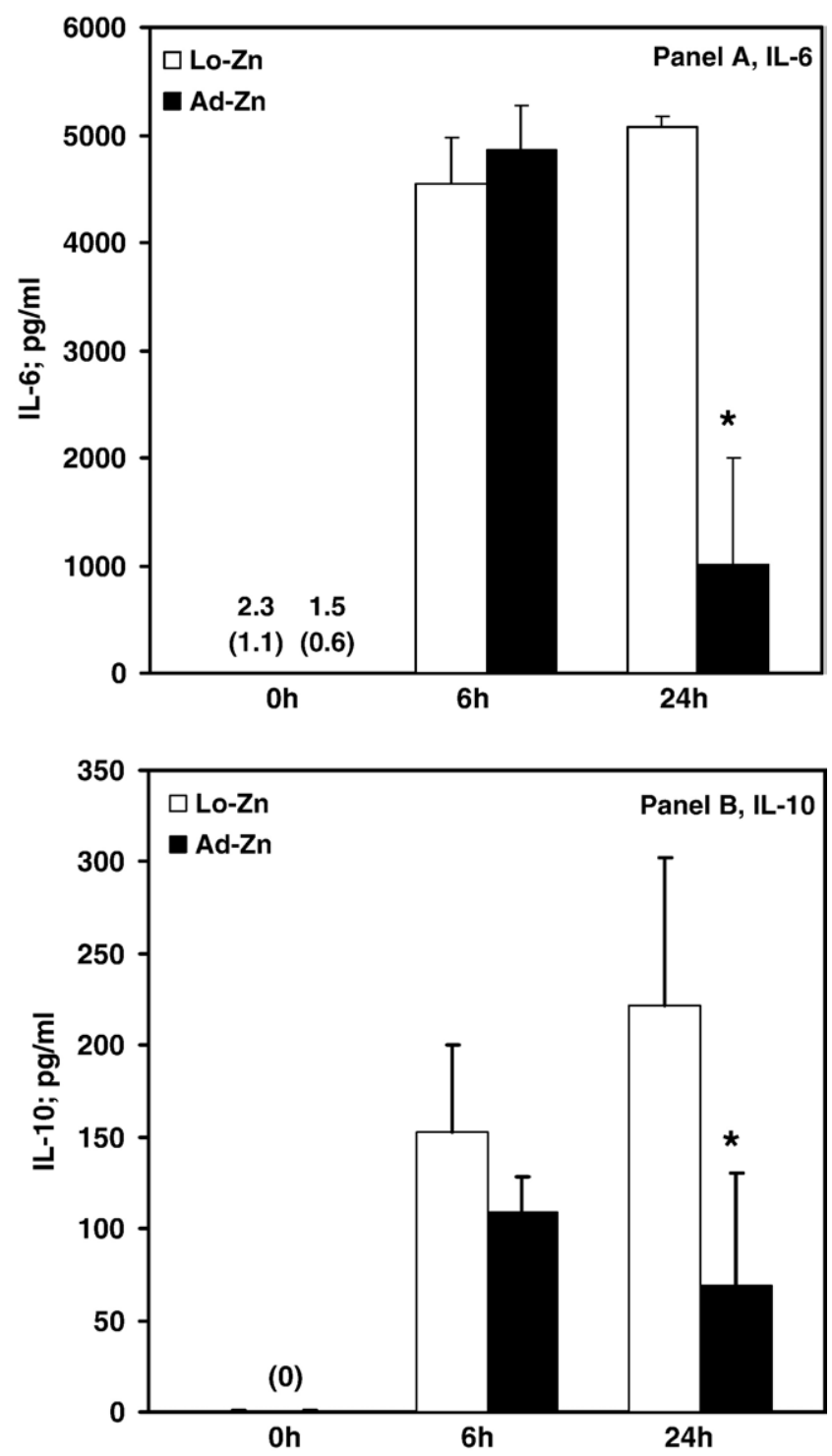

Fig. 1. IL-6 (A) and IL-10 (B) are induced $6 \mathrm{~h}$ after the immune challenge and remain elevated at $24 \mathrm{~h}$ in $\mathrm{Zn}$-marginal (Lo-Zn) mice but decline in $\mathrm{Zn}$ adequate $(\mathrm{Ad}-\mathrm{Zn})$ mice. Mice were challenged with intraperitoneal injection of LPS and then sacrificed 6 and $24 \mathrm{~h}$ after the challenge. Serum was collected, and serum IL- 6 and IL-10 protein concentrations were determined. IL-6 values $0 \mathrm{~h}$ after the challenge are presented as mean (S.E.M.); IL-10 was not detected $0 \mathrm{~h}$ after the challenge. Asterisks indicate significant difference between the Lo- $\mathrm{Zn}$ and Ad-Zn animals $(P<.05)$; error bars represent S.E.M.
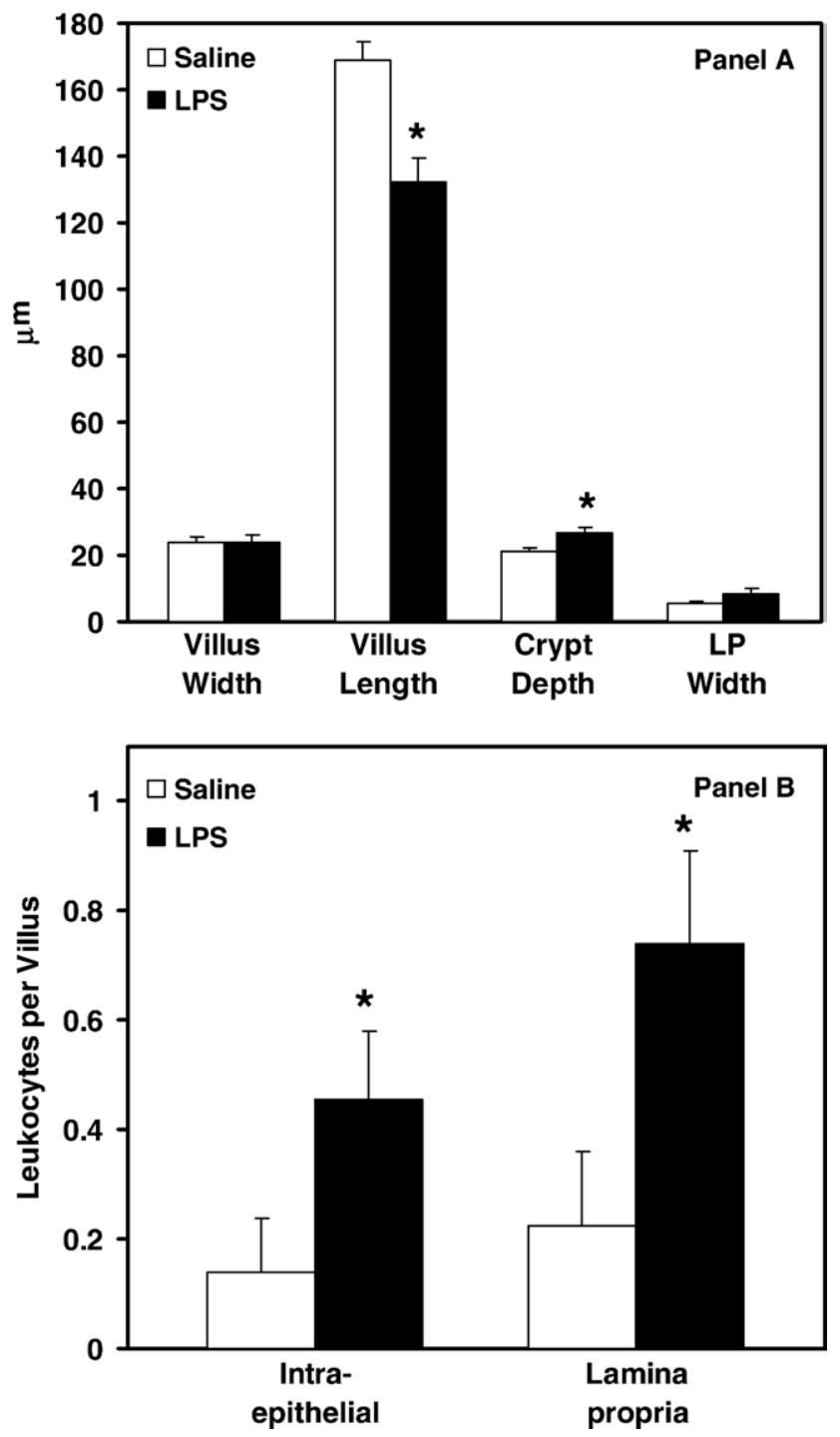

Fig. 2. Effects of immune challenge (white bars indicate saline control; black bars, LPS) on intestinal morphology (A) and leukocyte recruitment (B) in the jejunum of Ad-Zn and Lo- $\mathrm{Zn}$ animals. Significant differences due to the challenge are noted by an asterisk $(P<.05)$; error bars represent S.E.M.

leukocytes in the intraepithelial region as well as a significant increase in LP leukocyte numbers $(P<.05$; Fig. 5B). Diet also affected ileum histology; animals fed with the Zn-marginal diet had greater villus length and crypt depth as compared with the $\mathrm{Zn}$-adequate animals $(P<.05$; Fig. 6A). Finally, the Zn-marginal diet led to a significantly greater number of leukocytes in the LP region as compared with animals fed with the $\mathrm{Zn}$-adequate $\operatorname{diet}(P<.05$; Fig. $6 \mathrm{~B})$.

\section{Discussion}

This experiment demonstrates that an intraperitoneal LPS challenge is sufficient to induce intestinal inflammation. In this experiment, immune challenge generally increased crypt depth and the number of leukocytes in the jejunum and 
ileum, all of which are responses typical of intestinal inflammation. In response to cytokines and other chemical mediators induced by an enteric challenge, leukocyte infiltration occurs via interaction of leukocyte integrins and endothelial cell surface adhesion molecules such as intracellular adhesion molecule [18]. As a result of leukocyte infiltration to the intestine, crypt abscess formation may be induced, as seen in the current trial in the form of increased crypt depth. Additionally, excessive inflammation in the intestine may reduce enterocyte barrier function, thus allowing additional bacterial and inflammatory challenges to occur (reviewed in Reference [24]).

In addition to intestinal inflammation, systemic inflammation was induced, as evidenced by changes in plasma cytokines as well as behavior. In terms of behavioral
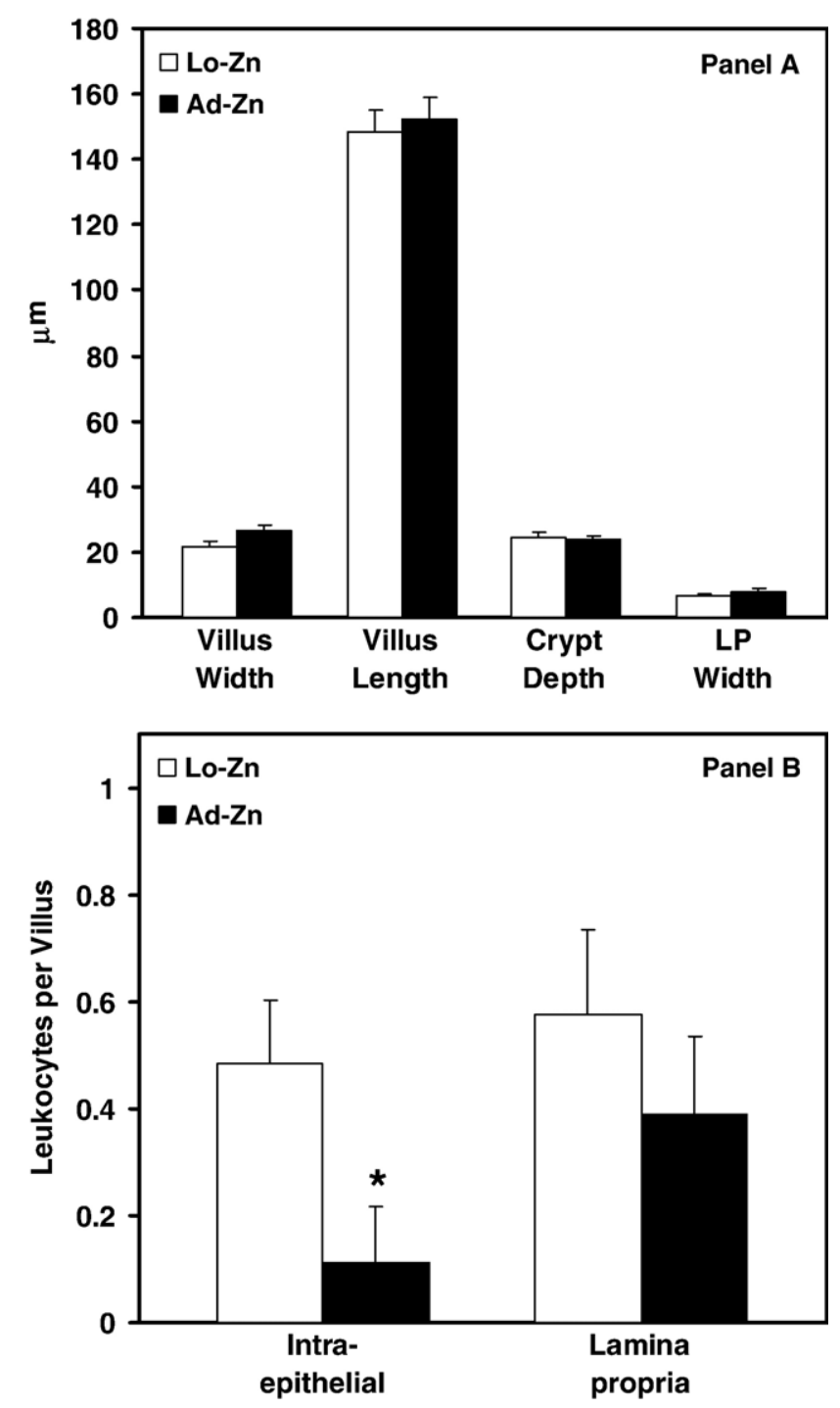

Fig. 3. Effects of diet (white bars indicate Lo-Zn mice; black bars, Ad-Zn mice) on intestinal morphology (A) and leukocyte recruitment (B) in the jejunum of LPS-challenged and nonchallenged animals combined. Significant differences due to diet are noted by an asterisk $(P<.05)$; error bars represent S.E.M.

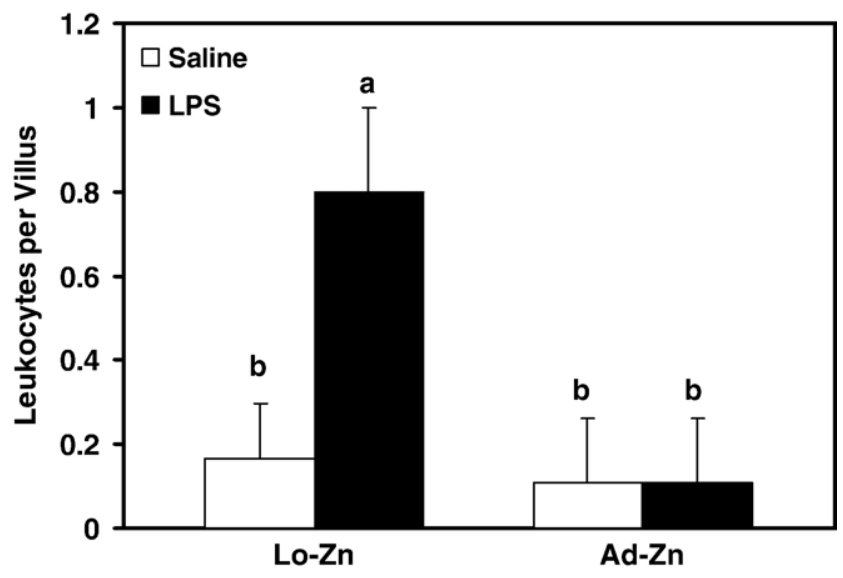

Fig. 4. Interaction of immune challenge with LPS or saline (control) and $\mathrm{Zn}$ status on leukocyte recruitment in the intraepithelial region of the jejunum. Different letters indicate significant differences $(P<05)$; error bars represent S.E.M.

responses, LPS-challenged mice had substantially reduced exploratory activity. Previous trials have shown that an LPS challenge reduces the frequency of typical behaviors, particularly in dominant animals [25], and this response is likely due to cytokine action on the brain; LPS has been shown to induce TNF $\alpha$, IFN $\gamma$ and IL-10 in a similar mouse enteric challenge model [26] as well as IL-6, IL-10 and TNF $\alpha$ in a cecal ligation model of sepsis [27]. Similarly, the LPS challenge in the current trial increased secretion of IL-6, IL-10, IFN $\gamma$ and TNF $\alpha$.

Dietary $\mathrm{Zn}$ status also affected cytokine secretion and intestinal leukocyte numbers. The LPS challenge elicited a similar and pronounced immune response in all animals, but the response in the $\mathrm{Zn}$-restricted mice was prolonged as compared with that in the mice fed with adequate $\mathrm{Zn}$ in terms of IL-6 and IL-10 and in terms of intestinal leukocyte numbers. IL-6 is generally considered to be pro-inflammatory (e.g., [28]), while IL-10 is anti-inflammatory [29] — in addition, its levels are generally correlated with those of IL-6 during bacterial infection [30]. In this trial, inflammatory responses appeared to overwhelm anti-inflammatory parameters in Zn-restricted mice since enhanced intestinal leukocyte infiltration was observed after the LPS challenge in these animals. The implications of prolonged inflammation and leukocyte infiltration in the intestine are substantial; resolution of intestinal inflammation is critical for host survival due to alterations in intestinal permeability and loss of nutrients and water, increased bacterial translocation and other detrimental effects on host physiology (reviewed in References [24,31]). It has been shown that adequate $\mathrm{Zn}$ status prevents barrier disruption in the enterocyte monolayer as well as bacterial adhesion and internalization [15], which result in intestinal immune activation [32]. Further experimentation will be required to elucidate the mechanistic basis for the observed interaction between diet and LPS challenge on IL-6, IL-10 and leukocyte recruitment. 

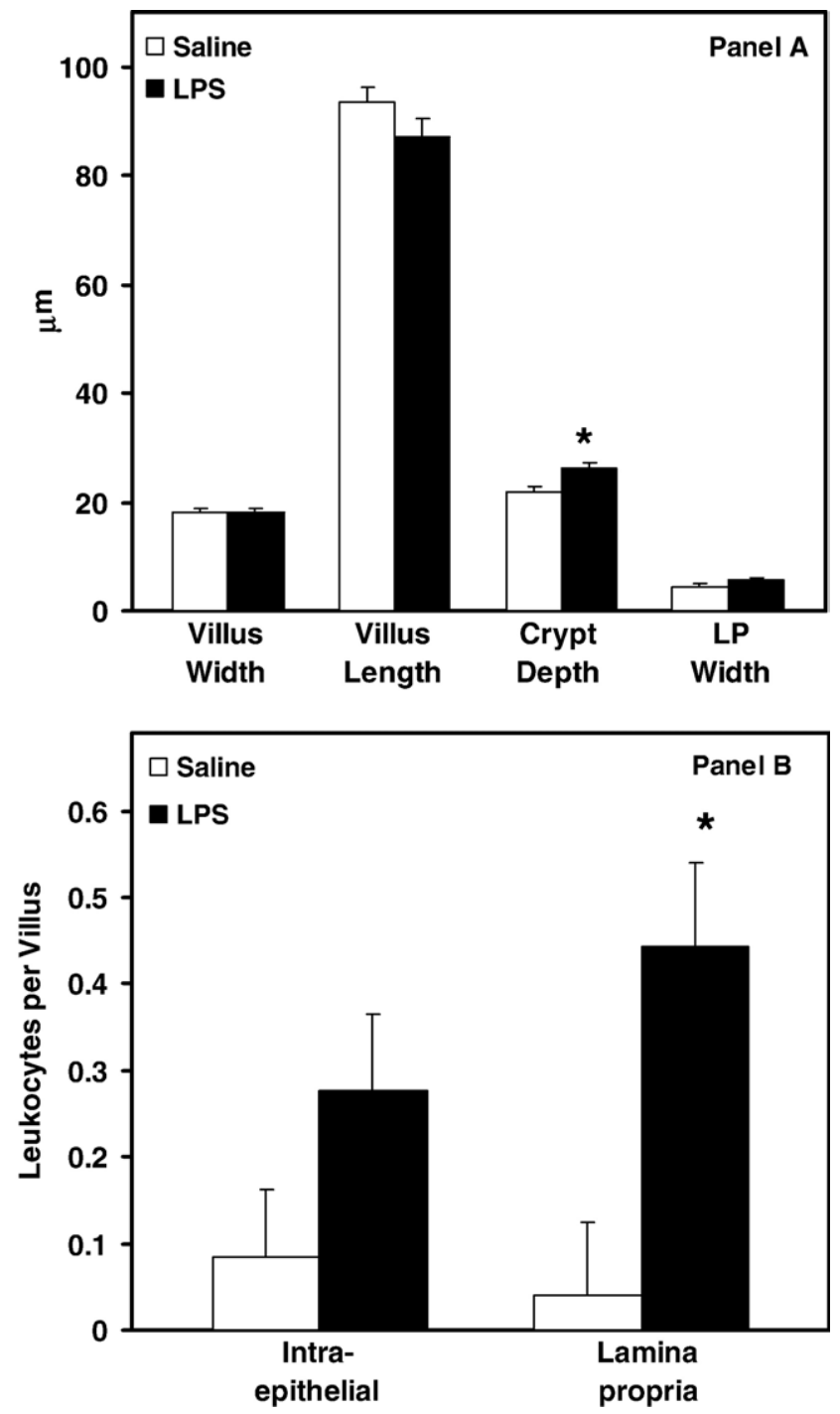

Fig. 5. Effects of immune challenge (white bars indicate saline control; black bars, LPS) on intestinal morphology (A) and leukocyte recruitment (B) in the ileum of Ad- $\mathrm{Zn}$ and Lo- $\mathrm{Zn}$ animals combined. Significant differences due to the challenge are noted by an asterisk $(P<.05)$; error bars represent S.E.M.

Interestingly, previous trials have not shown effects of $\mathrm{Zn}$ status on IL-10, although $\mathrm{Zn}$ deficiency has been associated with increased production of IL-2 and IFN $\gamma$ by T helper cells [10]. The mechanism by which $\mathrm{Zn}$ status may have affected IL-10 and IL-6 production in the current trial may be via effects on nuclear factor-kappa B (NF- $\mathrm{B})$ and peroxisome proliferator-activated receptor gamma (PPAR $\gamma)$. PPAR $\gamma$ is known to suppress expression of inflammatory cytokines [33], and $\mathrm{Zn}$ deficiency has been shown to reduce PPAR $\gamma$ expression and increase $\mathrm{NF}-\kappa \mathrm{B}$ activation in endothelial cells [34]. Regardless of the mechanism, enhancement of IL10 is negatively correlated with survival during bacterial challenges in humans [30].

In contrast to its effects on immune responses, moderate $\mathrm{Zn}$ restriction in adult mice for 4 weeks had little effect on feed intake and BW. Given that mice were at maintenance and that the level of $\mathrm{Zn}$ deficiency was moderate - and for a relatively short period, this response is not surprising. In growing animals, similar levels of dietary $\mathrm{Zn}$ have been shown to result in reduced growth rate and feed intake due to direct effects on appetite-related gene expression in the pituitary [35]. The lack of effect on BW and intake in the present study despite a 10 -fold difference in dietary $\mathrm{Zn}$ content supports the notion that the $\mathrm{Zn}$ deficiency that these animals experienced was only moderate.

In summary, this trial demonstrates that an intraperitoneal challenge with LPS is sufficient to induce intestinal inflammation and systemic inflammation. Moderate $\mathrm{Zn}$ restriction in adult mice altered the response to LPS and generally resulted in prolonged systemic cytokine levels and increased leukocyte infiltration in the small intestine. These changes may contribute to the etiology of diarrhea and other
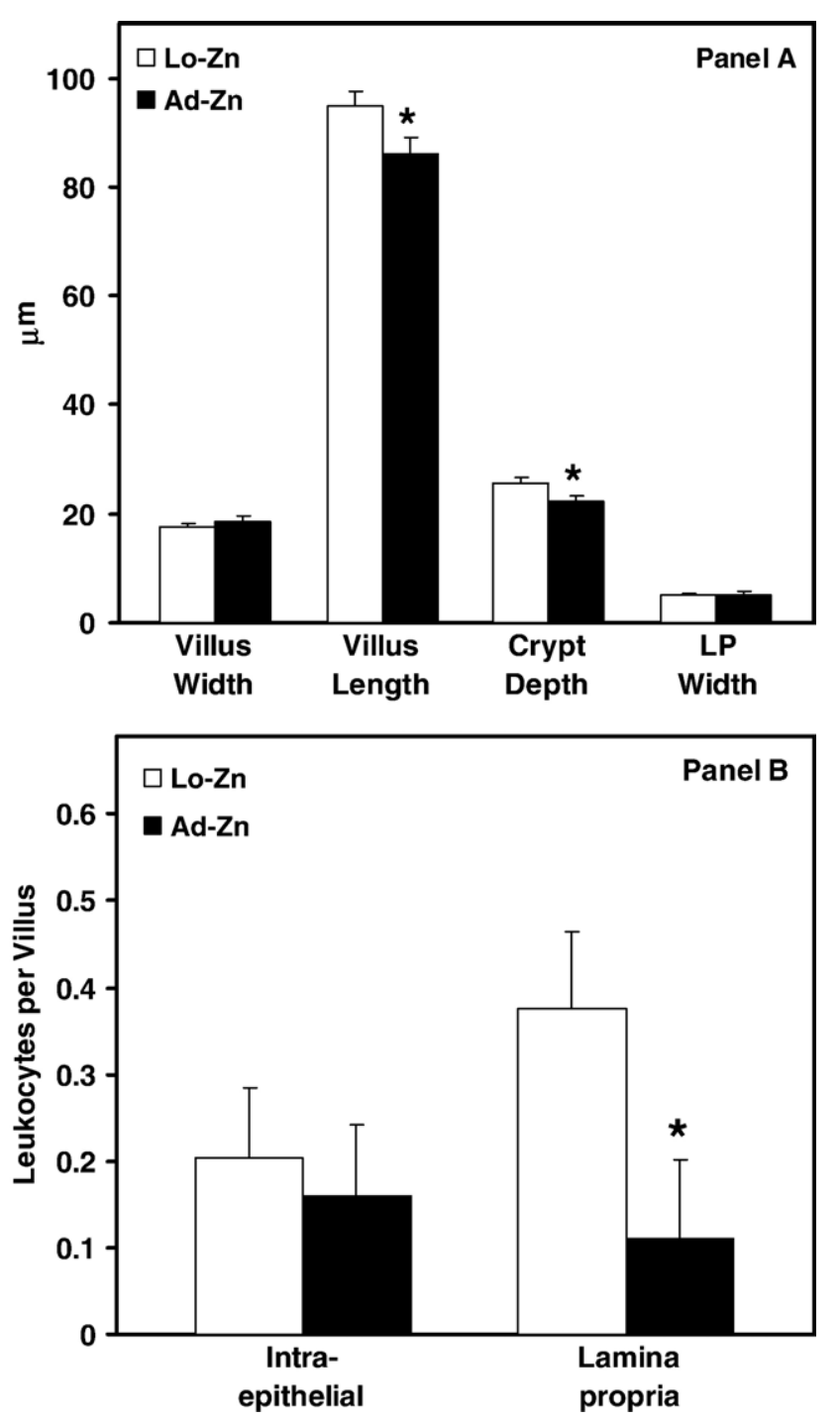

Fig. 6. Effects of diet (white bars indicate Lo-Zn mice; black bars, Ad-Zn mice) on intestinal morphology (A) and leukocyte recruitment (B) in the ileum of LPS-challenged and nonchallenged animals combined. Significant differences due to diet are noted by an asterisk $(P<.05)$; error bars represent S.E.M. 
issues associated with immunocompetence observed in $\mathrm{Zn}$ deficiency, and this study demonstrates that even moderate $\mathrm{Zn}$ restriction for a short period may affect immune function.

\section{References}

[1] Ibs KH, Rink L. Zinc-altered immune function. J Nutr 2003;133: 1452S-6S.

[2] Keen CL, Gershwin ME. Zinc deficiency and immune function. Annu Rev Nutr 1990;10:415-31.

[3] Shankar AH, Prasad AS. Zinc and immune function: the biological basis of altered resistance to infection. Am J Clin Nutr 1998;68:447S-63S.

[4] Fraker PJ, Gershwin ME, Good RA, Prasad A. Interrelationships between zinc and immune function. Fed Proc 1986;45:1474-9.

[5] Fraker PJ, King LE, Laakko T, Vollmer TL. The dynamic link between the integrity of the immune system and zinc status. J Nutr 2000;130:1399S-406S.

[6] Beck FW, Prasad AS, Kaplan J, Fitzgerald JT, Brewer GJ. Changes in cytokine production and $\mathrm{T}$ cell subpopulations in experimentally induced zinc-deficient humans. Am J Physiol 1997;272:E1002-7.

[7] Unoshima M, Nishizono A, Takita-Sonoda Y, Iwasaka H, Noguchi T. Effects of zinc acetate on splenocytes of endotoxemic mice: enhanced immune response, reduced apoptosis, and increased expression of heat shock protein 70. J Lab Clin Med 2001;137:28-37.

[8] Aydemir TB, Blanchard RK, Cousins RJ. Zinc supplementation of young men alters metallothionein, zinc transporter, and cytokine gene expression in leukocyte populations. Proc Natl Acad Sci U S A 2006;103:1699-704.

[9] Tanaka Y, Shiozawa S, Morimoto I, Fujita T. Role of zinc in interleukin 2 (IL-2)-mediated T-cell activation. Scand J Immunol 1990;31:547-52.

[10] Bao B, Prasad A, Beck FW, Godmere M. Zinc modulates mRNA levels of cytokines. Am J Physiol Endocrinol Metab 2003;285:1095-102.

[11] Hennig B, Meerarani P, Toborek M, McClain C. Antioxidant-like properties of zinc in activated endothelial cells. J Am Coll Nutr 1999; 18:152-8.

[12] Rodriguez P, Darmon N, Chappuis P, Candalh C, Blaton MA, Bouchaud $\mathrm{C}$, et al. Intestinal paracellular permeability during malnutrition in guinea pigs: effect of high dietary zinc. Gut 1996;39:416-22.

[13] Owusu-Asiedu A, Nyachoti CM, Marquardt RR. Response of earlyweaned pigs to an enterotoxigenic Escherichia coli (K88) challenge when fed diets containing spray-dried porcine plasma or pea protein isolate plus egg yolk antibody, zinc oxide, fumaric acid, or antibiotic. J Anim Sci 2003;81:1790-8.

[14] Sawai J. Quantitative evaluation of antibacterial activities of metallic oxide powders $(\mathrm{ZnO}, \mathrm{MgO}$ and $\mathrm{CaO})$ by conductimetric assay. J Microbiol Methods 2003;54:177-82.

[15] Roselli M, Finamore A, Garaguso I, Britti MS, Mengheri E. Zinc oxide protects cultured enterocytes from the damage induced by Escherichia coli. J Nutr 2003;133:4077-82.

[16] Hambidge KM, Hambidge C, Jacobs M, Baum JD. Low levels of zinc in hair, anorexia, poor growth, and hypogeusia in children. Pediatr Res 1972;6:868-74.

[17] Gibson RS, Vanderkooy PD, MacDonald AC, Goldman A, Ryan BA, Berry M. A growth-limiting, mild zinc-deficiency syndrome in some southern Ontario boys with low height percentiles. Am J Clin Nutr 1989;49:1266-73.
[18] Ishii N, Tsuzuki Y, Matsuzaki K, Miyazaki J, Okada Y, Hokari R, et al. Endotoxin stimulates monocyte-endothelial cell interactions in mouse intestinal Peyer's patches and villus mucosa. Clin Exp Immunol 2004;135:226-32.

[19] Cravatt BF, Demarest K, Patricelli MP, Bracey MH, Giang DK, Martin $\mathrm{BR}$, et al. Supersensitivity to anandamide and enhanced endogenous cannabinoid signaling in mice lacking fatty acid amide hydrolase. Proc Natl Acad Sci U S A 2001;98:9371-6.

[20] Iji PA, Saki A, Tivey DR. Body and intestinal growth of broiler chicks on a commercial starter diet: 3. Development and characteristics of tryptophan transport. Br Poult Sci 2001;42:523-9.

[21] Mestecky J, Moldoveanu Z, Elson CO. Immune response versus mucosal tolerance to mucosally administered antigens. Vaccine 2005;23:1800-3.

[22] Sanderson IR. The innate immune system of the gastrointestinal tract. Mol Immunol 2003;40:393-4.

[23] Bjerregaard P. Lymphoid cells in chicken intestinal epithelium. Cell Tissue Res 1975;161:485-95.

[24] Gewirtz AT, Liu Y, Sitaraman SV, Madara JL. Intestinal epithelial pathobiology: past, present and future. Best Pract Res Clin Gastroenterol 2002;16:851-67.

[25] Cohn DW, de Sa-Rocha LC. Differential effects of lipopolysaccharide in the social behavior of dominant and submissive mice. Physiol Behav 2006;87:932-7.

[26] Matalka KZ, Tutunji MF, Abu-Baker M, Abu Baker Y. Measurement of protein cytokines in tissue extracts by enzyme-linked immunosorbent assays: application to lipopolysaccharide-induced differential milieu of cytokines. Neuro Endocrinol Lett 2005;26:231-6.

[27] Vianna RC, Gomes RN, Bozza FA, Amancio RT, Bozza PT, David $\mathrm{CM}$, et al. Antibiotic treatment in a murine model of sepsis: impact on cytokines and endotoxin release. Shock 2004;21:115-20.

[28] Waage A, Brandtzaeg P, Halstensen A, Kierulf P, Espevik T. The complex pattern of cytokines in serum from patients with meningococcal septic shock. Association between interleukin 6, interleukin 1, and fatal outcome. J Exp Med 1989;169:333-8.

[29] Zhou P, Streutker C, Borojevic R, Wang Y, Croitoru K. IL-10 modulates intestinal damage and epithelial cell apoptosis in $\mathrm{T}$ cellmediated enteropathy. Am J Physiol Gastrointest Liver Physiol 2004;287:G599-604.

[30] Lehmann AK, Halstensen A, Sornes S, Rokke O, Waage A. High levels of interleukin 10 in serum are associated with fatality in meningococcal disease. Infect Immun 1995;63:2109-12.

[31] Chandra RK. Nutrition and immunoregulation. Significance for host resistance to tumors and infectious diseases in humans and rodents. J Nutr 1992;122:754-7.

[32] Nussler NC, Stange B, Nussler AK, Settmacher U, Langrehr JM, Neuhaus P, et al. Upregulation of intraepithelial lymphocyte (IEL) function in the small intestinal mucosa in sepsis. Shock 2001;16:454-8.

[33] Jiang C, Ting AT, Seed B. PPAR-gamma agonists inhibit production of monocyte inflammatory cytokines. Nature 1998;391:82-6.

[34] Meerarani P, Reiterer G, Toborek M, Hennig B. Zinc modulates PPARgamma signaling and activation of porcine endothelial cells. J Nutr 2003;133:3058-64.

[35] Sun JY, Jing MY, Wang JF, Zi NT, Fu LJ, Lu MQ, et al. Effect of zinc on biochemical parameters and changes in related gene expression assessed by cDNA microarrays in pituitary of growing rats. Nutrition 2006;22:187-96. 